\title{
Bioavailability of zinc and phosphorus in calcareous soils as affected by citrate exudation
}

\author{
Andreas Duffner • Ellis Hoffland • \\ Erwin J. M. Temminghoff
}

Received: 13 February 2012 / Accepted: 24 April 2012 /Published online: 12 May 2012

(C) The Author(s) 2012. This article is published with open access at Springerlink.com

\begin{abstract}
Aims Zinc (Zn) and phosphorus (P) deficiency often occurs at the same time and limits crop production in many soils. It has been suggested that citrate root exudation is a response of plants to both deficiencies. We used white lupin (Lupinus albus L.) as a model plant to clarify if citrate exuded by roots could increase the bioavailability of $\mathrm{Zn}$ and $\mathrm{P}$ in calcareous soils.

Methods White lupin was grown in nutrient solution and in two calcareous soils in a rhizobox. Rhizosphere soil solution was sampled to determine citrate, metals and P. Based on the measured citrate concentrations, a soil extraction experiment with citrate as extractant was done.

Results Absence of $\mathrm{Zn}$ triggered neither cluster root formation nor citrate exudation of white lupin grown in nutrient solution, whereas low $\mathrm{P}$ supply did. The maximum citrate concentration $(\sim 1.5 \mathrm{mM})$ found in the cluster rhizosphere soil solution of one soil mobilized $\mathrm{P}$, but not $\mathrm{Zn}$. In the other soil the highest citrate concentration $(\sim 0.5 \mathrm{mM})$ mobilized both elements. Conclusions White lupin does not respond to low $\mathrm{Zn}$ bioavailability by increasing citrate exudation. Such a
\end{abstract}

Responsible Editor: Ismail Cakmak.

A. Duffner $(\bowtie) \cdot$ E. Hoffland • E. J. M. Temminghoff Department of Soil Quality, Wageningen University, P.O. Box 47, 6700 AA Wageningen, The Netherlands e-mail: andreas.duffner@wur.nl response was observed at low $\mathrm{P}$ supply only. Whether $\mathrm{Zn}$ and $\mathrm{P}$ can be mobilized by citrate is soil-dependent and the possible controlling mechanisms are discussed.

Keywords Rhizosphere · Bioavailability · White lupin $\cdot$ Citrate $\cdot$ Zinc $\cdot$ Calcareous soils
Abbreviations
DAG Days after germination
CE Capillary electrophoresis
ICP- Inductively coupled plasma mass
MS spectroscopy
SOC Soil organic carbon
CEC Cation exchange capacity
CBD Citrate-bicarbonate-dithionite
OM Organic matter

\section{Introduction}

Zinc $(\mathrm{Zn})$ deficiency is limiting crop production in $\pm 30 \%$ of the world's soils (Sillanpää and Vlek 1985). Most of these soils are calcareous. In these areas, $\mathrm{Zn}$ deficiency is often caused not by low total soil $\mathrm{Zn}$ contents but by low bioavailability of $\mathrm{Zn}$ (Alloway 2009). Zinc deficiency often co-occurs with $\mathrm{P}$ deficiency, because the bioavailability of both elements decreases with increasing $\mathrm{pH}$ ( $\mathrm{Zhu}$ et al. 2001). At neutral $\mathrm{pH}(\mathrm{pH}<8.4) \mathrm{Zn}$ solubility is mainly 
controlled by adsorption reactions (Catlett et al. 2002) and $\mathrm{P}$ can precipitate as Ca-phosphate (Weng et al. 2011). Quijano-Guerta et al. (2002) studied the tolerance of rice (Oryza sativa L.) germplasm to $\mathrm{Zn}$ deficiency. They showed that genotypes tolerant to $\mathrm{Zn}$ deficiency also have at least a moderate tolerance to $\mathrm{P}$ deficiency. Hoffland et al. (2006) related these characteristics of multiple tolerance to citrate exudation.

Mobilization of $\mathrm{Zn}$ and $\mathrm{P}$ by citrate is based on different mechanisms. The free $\mathrm{Zn}$ ion $\left(\mathrm{Zn}^{2+}\right)$ is considered as the main bioavailable species (Kalis et al. 2007). Zinc mobilization is based on acidification due to the exudation of protons (Hinsinger et al. 2003) and on formation of soluble complexes of exuded citrate with $\mathrm{Zn}^{2+}$ in solution, which reduces the activity of $\mathrm{Zn}^{2}$ ${ }^{+}$in the soil solution. As a consequence $\mathrm{Zn}^{2+}$ desorbs from soil surfaces or dissolves from labile solid phases to replenish $\mathrm{Zn}^{2+}$ in solution (Lindsay and Norvell 1978). Phosphate mobilization from soils by citrate and proton exudation is attributed to (i) the enhanced dissolution of $\mathrm{P}$ minerals caused by acidification and complexation of cations such as calcium (in alkaline soils), aluminum and iron (in acid soils) from phosphate minerals by citrate, and (ii) the competitive adsorption of phosphate and citrate on metal (hydr)oxides (Geelhoed et al. 1998).

Although it is well documented that citrate (and protons) is able to mobilize P in soil (Hoffland 1992; Geelhoed et al. 1999; Kirk et al. 1999; Hinsinger 2001; Oburger et al. 2011), there are contrasting reports on root exudation of citrate or other low molecular weight organic acids under Zn deficiency and/ or their potential to mobilize $\mathrm{Zn}$ in soil. On the one hand Rose et al. (2011) proposed that enhanced exudation of malate, but not citrate, is a response of $\mathrm{Zn}$ efficient rice genotypes to $\mathrm{Zn}$ deficiency. Widodo et al. (2010) stated that the high tolerance of rice cultivars to $\mathrm{Zn}$ deficiency is most likely a result of malate exudation. Neither of these studies, however, proved Zn mobilization from soil by citrate. Degryse et al. (2008) showed that carboxylates exuded from roots of spinach (Spinacia oleracea L.) and tomato (Solanum lycopersicum L.) were able to mobilize $\mathrm{Cu}$ and $\mathrm{Zn}$ from a calcareous soil. On the other hand Gao et al. (2009) showed that malate concentrations observed in the rhizosphere of rice had a negligible effect on the concentration of $\mathrm{Zn}$ in soil solution of a low $\mathrm{Zn}$ soil.

We aimed to test the effectiveness of citrate exudation as response to low $\mathrm{Zn}$ and $\mathrm{P}$ in calcareous soils.
White lupin (Lupinus albus L.) is a useful model plant to study mobilization, because it is known from noncalcareous soils that white lupin shows a strong and effective response to low $\mathrm{P}$ supply by the formation of cluster roots (bottlebrush-like clusters of rootlets (Purnell 1960)) and exudation of citrate and protons (Dinkelaker et al. 1995; Weisskopf et al. 2006). Citrate concentrations can reach $\mathrm{m} M$ levels in the rhizosphere solution of cluster roots (Dessureault-Rompré et al. 2008). Gardner et al. (1982) showed that white lupin grown on an alkaline soil also responds to iron stress by the development of a higher proportion of cluster roots and an increase in proton and reducing and chelating compound production. However, to our best knowledge, such a response was not yet shown for white lupin under $\mathrm{Zn}$ deficiency conditions.

There are different approaches to determine a possible multiple stress response to low $\mathrm{Zn}$ and $\mathrm{P}$ bioavailability in the rhizosphere. One is the use of rhizoboxes in combination with micro-suction cups (Göttlein et al. 1996) which were already used with different plants and soils (Wenzel et al. 2001; Dessureault-Rompré et al. 2008; Gao et al. 2009). In the present study we determined in situ $\mathrm{Zn}$ and $\mathrm{P}$ mobilization by citrate in the rhizosphere of calcareous soils and linked potential $\mathrm{Zn}$ and $\mathrm{P}$ mobilization to plant uptake and the results of a nutrient solution and a soil extraction experiment.

\section{Material and methods}

Nutrient solution experiment

With a nutrient solution experiment we studied the formation of cluster roots and the exudation of citrate by white lupin in absence of $\mathrm{Zn}$ and P. White lupin (Lupinus albus L. var. Feodora) seeds were germinated in quartz sand and were transplanted after 5 days to $50 \mathrm{~L}$ containers filled with a continuously aerated nutrient solution. The composition of the nutrient solution was based on Jaitz et al. (2011). The $\mathrm{pH}$ of the nutrient solution was adjusted to $7.3( \pm 0.2)$. In addition to the control treatment containing all nutrients, there were two other treatments: either without $\mathrm{P}$ or without $\mathrm{Zn}$. After 21 days of growth, each plant was put individually in a Petri dish with $30 \mathrm{~mL} 1 \mathrm{mM}$ $\mathrm{CaCl}_{2}$ solution to determine the citrate exudation rate (Neumann and Römheld 2007). Two hours later, a 
sample of $10 \mathrm{~mL}$ was taken from the solution. After filtration $(0.45 \mu \mathrm{m}), 50 \mu \mathrm{L}$ of $\mathrm{CHCl}_{3}$ was added to avoid microbial degradation and the samples were analyzed for citrate and nitrate using capillary electrophoresis (CE) (see below). The citrate exudation rate was determined for four individual plants per treatment $(n=4)$. After collecting root exudates, roots were scanned on a root scanner followed by drying the roots at $70{ }^{\circ} \mathrm{C}$ for root dry weight determination.

\section{Soils}

Soil samples were collected in Hofuf (Saudi Arabia) and Anatolia (Turkey) from the top layer $(0-20 \mathrm{~cm})$. The soils are named after the location of collection. The sampling sites were used for crop cultivation and both soils were classified as Aridisols. In crops grown on Hofuf soil Fe chlorosis (Schenkeveld et al. 2008) and in crops grown on Anatolia soil $\mathrm{Zn}$ chlorosis (Cakmak et al. 1996) was manifested, respectively. The pre-treatment of the soil samples consisted of drying $\left(40{ }^{\circ} \mathrm{C}\right)$, sieving $(2 \mathrm{~mm})$ and homogenizing. The soil characteristics are shown in Table 1 . The $\mathrm{pH}$ and aqua regia extractable $\mathrm{Zn}$ fractions of the two soils are comparable. The DTPA extractable Zn (Lindsay and Norvell 1978) in the loamy Anatolia soil was five times lower than in the sandy Hofuf soil (Table 1). For quality assurance, reference samples from clay and sandy soils were analyzed (respectively ISE 989 and ISE 949, WEPAL, www.wepal.nl).

\section{Rhizobox experiment}

With a rhizobox experiment we investigated how the rhizosphere is affected by the response of white lupin to $\mathrm{Zn}$ and $\mathrm{P}$ deficiency in the two soils (Anatolia and Hofuf). The experiment was conducted in a climate chamber at Wageningen University (photoperiod of $15 \mathrm{~h}(6: 00-21: 00 \mathrm{~h})$, light intensity $525 \mu \mathrm{M} \mathrm{m}^{-2} \mathrm{~s}^{-1}$, day/night temperature $25 / 18{ }^{\circ} \mathrm{C}$, rel. humidity $70 \%$ ). Rhizoboxes, so-called "Hohenheim" boxes (Luster et al. 2009) (33 cm long, $20 \mathrm{~cm}$ wide, and $1.5 \mathrm{~cm}$ deep) were filled with moistened soil to a dry bulk density of $1.1 \mathrm{~g} \mathrm{~cm}^{-3}$. Treatments included a combination of two $\mathrm{Zn}$ and two $\mathrm{P}$ levels (i.e. $-\mathrm{P} /-\mathrm{Zn},+\mathrm{P} /-\mathrm{Zn},-\mathrm{P} /+\mathrm{Zn}$ and $+\mathrm{P} /+\mathrm{Zn})$. Except for the $-\mathrm{P}$ and $-\mathrm{Zn}$ treatments the soil was fertilized with $100 \mathrm{mg} \mathrm{N} \mathrm{kg}^{-1}$ (as $\mathrm{Ca}\left(\mathrm{NO}_{3}\right)_{2}$ $4 \mathrm{H}_{2} \mathrm{O}$ ), $80 \mathrm{mg} \mathrm{P} \mathrm{kg}^{-1}$ (as $\mathrm{KH}_{2} \mathrm{PO}_{4}$ ), $100 \mathrm{mg} \mathrm{K} \mathrm{kg}{ }^{-1}$ (as $\mathrm{KCl}$ ), $10 \mathrm{mg} \mathrm{Zn} \mathrm{kg}{ }^{-1}$ (as $\mathrm{ZnCl}_{2}$ ) and $1.5 \mathrm{mg}$
$\mathrm{Fe} \mathrm{kg}^{-1}$ (as Fe-HBED,(Chaney 1988)), respectively. In the $-\mathrm{P}$ and $-\mathrm{Zn}$ treatment, $\mathrm{P}$ or $\mathrm{Zn}$, respectively was omitted. Each treatment was duplicated. The soil was adjusted to $60 \%$ of its water holding capacity every day.

Seeds of white lupin (Lupinus albus L. var. Feodora) were soaked in $10 \% \mathrm{H}_{2} \mathrm{O}_{2}$ for $10 \mathrm{~min}$. After a germination period of 4 days on moist (double-distilled water) paper tissue, the seedlings were transplanted to the rhizoboxes (two plants per rhizobox), which was defined as the first Day After Germination (DAG). The rhizoboxes were standing in racks at an angle of $30^{\circ}$ to force the roots to grow along the Plexiglas plate side, which enabled us to observe and localize the roots. The Plexiglas was covered most of the time with a plastic sheet to exclude any light effect on root growth. The other side of the rhizobox consisted of a non-transparent PVC sheet with a $5 \times 5 \mathrm{~mm}$ grid of holes (1.8 $\mathrm{mm}$ diameter) for insertion of micro-suction cups, which were used for in situ soil solution sampling. The design, pre-cleaning- and sampling procedure with the micro suction cups was done according to Shen and Hoffland (2007).

Soil solution was sampled in the rhizosphere of the cluster roots and in the bulk soil. Around the cluster roots 6-8 micro-suction cups were inserted per rhizobox at a distance of $\pm 1 \mathrm{~mm}$ from the rootlet. We considered soil which was more than $5 \mathrm{~cm}$ away from the roots as bulk soil. Between the 1st and the 11th day after the emergence of the cluster root (17-27 days after germination (DAG)) the soil solution was sampled every second day at 14:00 h (DessureaultRompré et al. 2007) for $2.5 \mathrm{~h}$, which yielded a volume of $\pm 0.2 \mathrm{~mL}$ per micro-suction cup. To obtain enough soil solution for analysis, the samples collected by 6-8 micro-suction cups per cluster root were mixed. In the Hofuf soil only one replicate was analysed 7 days $(+\mathrm{P} /-\mathrm{Zn}$ treatment) and 9 days $(-\mathrm{P} /+\mathrm{Zn}$ and $\mathrm{P} /-\mathrm{Zn}$ treatment) after cluster emergence, because the sample volume was too small to allow for replicates. The $\mathrm{pH}$ was determined immediately after sampling. The solution was subsequently divided into subsamples for the analysis of citrate and nitrate with Capillary Electrophoresis (see below) and of $\mathrm{Zn}, \mathrm{Fe}$ and $\mathrm{P}$ with Inductively Coupled Plasma Mass Spectroscopy (ICP-MS, Elan 6000, Perkin Elmer). The detection limit for $\mathrm{P}$ and $\mathrm{Zn}$ with ICP MS was $1 \mu \mathrm{g} \mathrm{L}^{-1}$ and $0.3 \mu \mathrm{g} \mathrm{L}^{-1}$, respectively. Phosphorus analysis with ICP-MS includes the inorganic and the organic P fractions. Roots and shoots were harvested 27 DAG. 
Table 1 Soil characteristics

\begin{tabular}{|c|c|c|c|c|c|c|c|c|c|}
\hline \multirow[t]{2}{*}{ Soil } & \multirow[t]{2}{*}{$\mathrm{pH}^{\mathrm{a}}$} & \multirow{2}{*}{$\begin{array}{l}\text { Clay } \\
\mathrm{g} \mathrm{kg}^{-1}\end{array}$} & \multirow{2}{*}{$\begin{array}{l}\mathrm{CaCO}_{3}{ }^{\mathrm{b}} \\
\mathrm{g} \mathrm{kg}^{-1}\end{array}$} & \multirow{2}{*}{$\begin{array}{l}\mathrm{SOC}^{\mathrm{c}} \\
\mathrm{g} \mathrm{kg}^{-1}\end{array}$} & \multirow{2}{*}{$\begin{array}{l}\mathrm{CEC}^{\mathrm{d}} \\
\mathrm{cmol}^{+} \mathrm{kg}^{-1}\end{array}$} & \multirow{2}{*}{$\begin{array}{l}\mathrm{CBD}^{\mathrm{e}} \\
\mathrm{Fe} \\
\mathrm{g} \mathrm{kg}^{-1}\end{array}$} & \multicolumn{2}{|c|}{$0.005 M$ DTPA $^{\mathrm{f}}$} & \multirow{2}{*}{$\begin{array}{l}\text { Aqua regia } \\
\mathrm{Zn}\end{array}$} \\
\hline & & & & & & & $\begin{array}{l}\mathrm{Zn} \\
\mathrm{mg} \mathrm{kg}^{-1}\end{array}$ & $\mathrm{Fe}$ & \\
\hline Hofuf ${ }^{\#}$ & 7.7 & 40 & 62 & 7.1 & 3.5 & 0.6 & 5.03 & 6.7 & 28 \\
\hline Anatolia & 7.9 & 220 & 93 & 10 & 32.1 & 5.1 & 0.09 & 11.2 & 33 \\
\hline
\end{tabular}

\# Data of Hofuf soil are from Schenkeveld et al. (2008)

${ }^{\mathrm{a}} 0.01 \mathrm{M} \mathrm{CaCl}_{2}$, ISO/DIS 10390; ${ }^{\mathrm{b}}$ ISO 10693, ${ }^{\mathrm{c}}$ Soil organic carbon, Walinga et al. (1992) $;{ }^{\mathrm{d}}$ Cation exchange capacity, ISO/DIS 11260 ;

${ }^{\mathrm{e}}$ Citrate Bicarbonate Dithionite, Holmgren (1967); ${ }^{\mathrm{f}}$ Lindsay and Norvell (1978); ${ }^{\mathrm{g}}$ ISO 11466

Roots were washed thoroughly with distilled water to remove all soil particles and the number of cluster roots per plant was counted followed by washing the roots for $1 \mathrm{~min}$ in a $0.01 \mathrm{M}$ EDTA solution to remove the root surface adsorbed metals (Kalis et al. 2007). Afterwards the roots and shoots were dried at $70{ }^{\circ} \mathrm{C}$ for 3 days to determine their dry weight and milled and digested according to the procedure described by Novozamsky et al. (1996). The Zn and P concentrations in digests were measured with ICP-MS. Plant uptake was calculated by summing the products of root and shoot dry weight and their respective tissue content of $\mathrm{P}$ and $\mathrm{Zn}$, minus the product of seed dry weight and seed tissue content of $\mathrm{P}$ and $\mathrm{Zn}$.

The rhizobox experiment was done twice, yielding highly similar results. Results of one of the two experiments are shown.

\section{Soil extraction experiment}

The soil extraction experiment with the Anatolia and Hofuf soils aimed to determine the $\mathrm{Zn}$ and $\mathrm{P}$ mobilizing capacity of citrate. Air-dried soil ( $3 \mathrm{~g})$ was added to a $50 \mathrm{~mL}$ centrifugation tube and $30 \mathrm{~mL}$ extraction solution was added (Houba et al. 2000). The extraction solution consisted of citric acid with a concentration range from 0 to $7 \mathrm{mM}$ in $0.01 \mathrm{M} \mathrm{CaCl}_{2}$. Hundred $\mu \mathrm{L}$ of $\mathrm{CHCl}_{3}$ was added to the extraction solution to avoid microbial degradation The tubes were shaken horizontally for $24 \mathrm{~h}$ at $20^{\circ} \mathrm{C}$. The $\mathrm{pH}$ in the suspensions was measured immediately after shaking, then the suspensions were centrifuged at $3000 \times \mathrm{g}$ for $10 \mathrm{~min}$, and the supernatants were filtered $(0.45 \mu \mathrm{m})$ before determining the concentrations of citrate (Capillary Electrophoresis, see below), $\mathrm{Zn}$ and $\mathrm{P}$ (ICP-MS). The experiment was done in duplicate.
Citrate and nitrate analysis

Citrate and nitrate were analyzed with capillary electrophoresis (CE) in adaptation to the method of Westergaard et al. (1998). The instrument (Waters Corp., Milford, MA, USA) was equipped with a UV detector (indirect) and a $254 \mathrm{~nm}$ filter. All separations were performed in a fused-silica capillary (accu-Sep $75 \mu \mathrm{m} \times 60 \mathrm{~cm}$ capillary, Waters Corp., Milford, MA, USA). Between two samples the capillary was rinsed with deionized water for $0.5 \mathrm{~min}$, with $0.1 \mathrm{M} \mathrm{NaOH}$ for $1 \mathrm{~min}$ and with deionized water for $0.5 \mathrm{~min}$, respectively, after which it was preconditioned with the background electrolyte for $3 \mathrm{~min}$. The background electrolyte was prepared with 1,2,4-benzenetri-carboxylic acid [TriMellitic Acid, (TMA)]. The electrolyte consisted of $3 \mathrm{mM}$ TMA and $0.02 \%(v / v)$ DiEthyleneTriAmine (DETA) with the $\mathrm{pH}$ adjusted to 5.8 with $\mathrm{NaOH}$. Cation interference (metal-organic anion complexes) was prevented by adding $50 \mu \mathrm{L}$ of a $25 \mathrm{mM}$ tetra-sodium-ethyleneditetraacetic $\left(\mathrm{Na}_{4} \mathrm{EDTA}, \mathrm{pH}>10\right)$ solution to each sample of $450 \mu \mathrm{L}$. The $\mathrm{CE}$ was run at $20{ }^{\circ} \mathrm{C}$ and the high voltage was set to $25 \mathrm{kV}$. The detection limit was $10 \mu M$.

\section{Statistical analysis}

Statistical analysis of data was performed with SPSS analytical software (SPSS Inc., Chicago, IL, USA; version 17). A two-way ANOVA was done to analyze main effects of the $\mathrm{P}$ and $\mathrm{Zn}$ treatments on shoot dry weight, on $\mathrm{Zn}$ and $\mathrm{P}$ plant uptake and on $\mathrm{Zn}, \mathrm{Fe}$ and $\mathrm{P}$ concentrations in the soil solution. The variation among data was homogeneous (Levene's test). Bivariate correlation was used to determine the Pearson correlation coefficient $(r)$ between the $\mathrm{P}$ or $\mathrm{Zn}$ contents 
in the shoot tissue and the number of cluster roots, respectively, with a two tailed test for significance $(P<0.05)$.

\section{Results}

Nutrient solution experiment

Cluster root formation was observed neither on plants grown in the nutrient solution without $\mathrm{Zn}$ nor on those grown in the complete nutrient solution. In the solution without added $\mathrm{P}$ considerable cluster root formation was observed (Fig. 1). Citrate exudation by root systems grown in $-\mathrm{Zn}$ and in complete nutrient solution was below the detection limit $(10 \mu M)$, which means that the exudation rate was below $\sim 0.8 \mu \mathrm{mol} \mathrm{g} \mathrm{g}^{-1} \mathrm{~h}^{-1}$. In the $-\mathrm{P}$ treatment, the exudation rate was $3.9 \mu \mathrm{mol} \mathrm{g} \mathrm{g}^{-1} \mathrm{~h}^{-1}$. The plants grown on the $-\mathrm{Zn}$ treatment showed $\mathrm{Zn}$ deficiency symptoms (chlorotic leaves with brown necrotic spots). Neither the plants grown in the nutrient solution without $\mathrm{P}$ nor those grown in the complete nutrient solution showed visible deficiency symptoms apart from growth reduction.

\section{Rhizobox experiment}

Plants of all treatments looked similar. No stress symptoms could be observed. Shoot dry weight was increased significantly ( $P=0.002)$ by $\mathrm{P}$ fertilization in the Anatolia soil, but not by $\mathrm{Zn}$ fertilization. Shoot dry weight of the plants grown in the Hofuf soil showed neither a response to $\mathrm{P}$ nor to $\mathrm{Zn}$ fertilization $(P>0.05)$ (Fig. 2a). Plant uptake of $\mathrm{P}$ and $\mathrm{Zn}$ increased significantly due to $\mathrm{P}(P \leq 0.0001)$ and $\mathrm{Zn}(P \leq 0.0001)$ fertilization on the Anatolia soil (Fig. 2b,c). Plants grown on the Hofuf soil responded to $\mathrm{P}(P=0.002)$, but not to $\mathrm{Zn}$ fertilization. Zinc uptake was significantly higher in the $-\mathrm{P} /-\mathrm{Zn}$ treatment than in the $+\mathrm{P} /-\mathrm{Zn}$ treatment from this soil (Fig. 2b,c).

Cluster root abundance in both soils was around 2.5 times higher in the $-\mathrm{P}$ compared to the $+\mathrm{P}$ treatments. The total number of cluster roots per plant in the $-\mathrm{P}$ treatment was about 20 and 8 in the Anatolia and the Hofuf soil, respectively. Phosphorous content in the shoot tissue of the Anatolia $(r=-0.88, P=0.04, n=8)$ and Hofuf soil $(r=-0.78, P=0.02, n=8)$ correlated negatively with the number of cluster roots per plant. The $\mathrm{Zn}$ content in the shoot tissue did not correlate with the number of cluster roots $(P>0.05)$.

Citrate concentrations in the soil solution of the cluster rhizosphere peaked 3 days after emergence of the cluster roots (Fig. 3). Maximum citrate concentrations in the Anatolia and Hofuf soils were about $1.5 \mathrm{~m} M$ and $0.5 \mathrm{~m} M$, respectively. At this point in time citrate concentrations in the $-\mathrm{P}$ treatments were significantly higher than in the $+\mathrm{P}$ treatments. $\mathrm{Zn}$
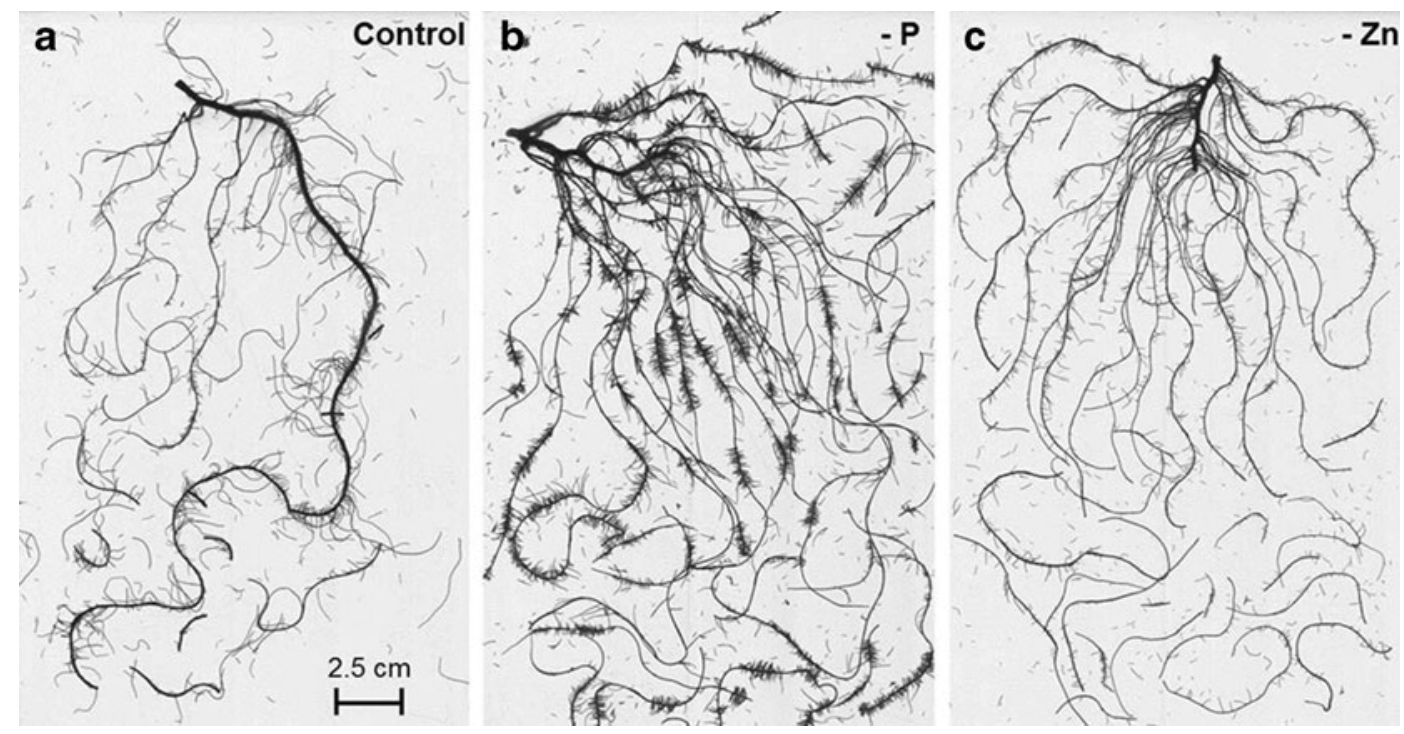

Fig. 1 Representative root system scans of white lupin plants grown in nutrient solution with all nutrients (a), without P (b), or without Zn (c). The bottle-brush-like clusters of rootlets in (b) are cluster roots 


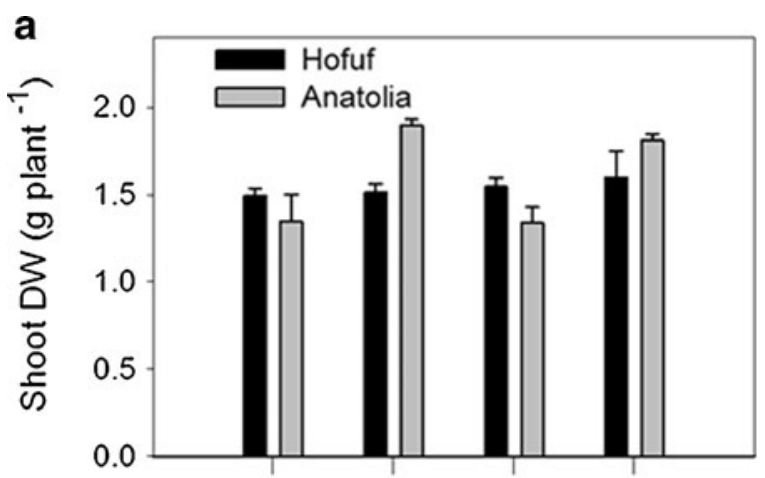

b
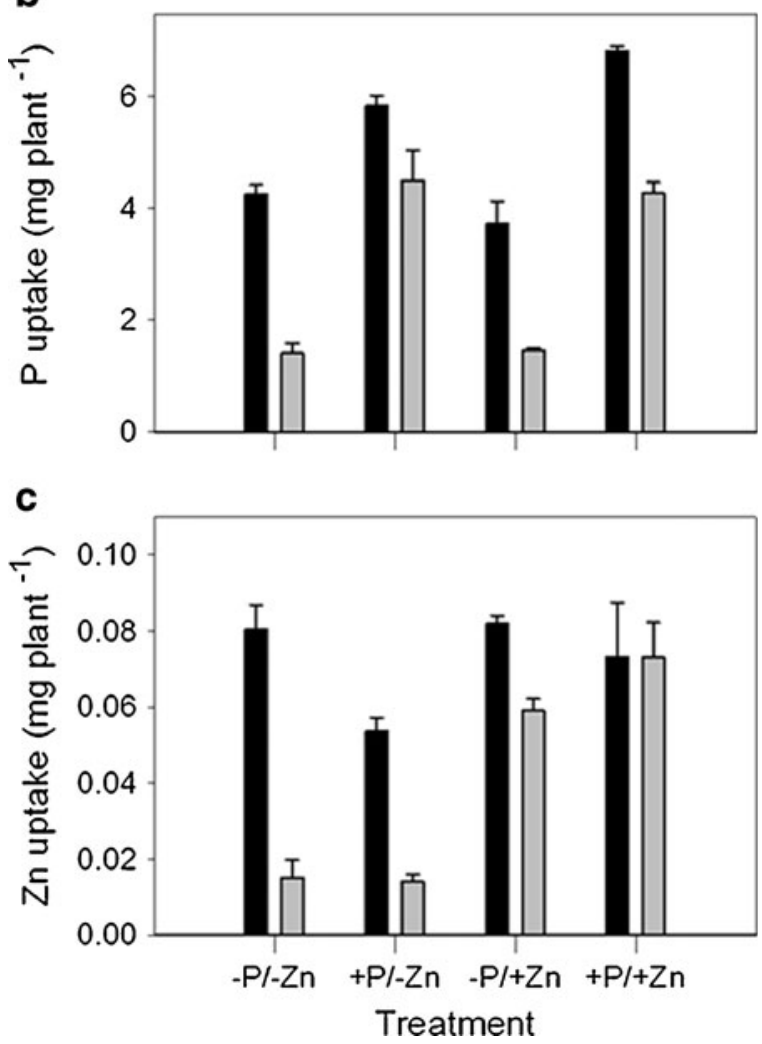

Fig. 2 Shoot dry weight (a), P plant uptake (b), and Zn plant uptake (c) of white lupin plants (27 days after germination) grown on two calcareous soils with $(+)$ and without $(-)$ fertilization with $\mathrm{Zn}$ or P. Error bars are standard errors $(n=2)$

fertilization did not affect the citrate concentrations in the cluster rhizopshere (Fig. 3). At the same time $\mathrm{Zn}$ and $\mathrm{P}$ application had increased the respective $\mathrm{Zn}$ and $\mathrm{P}$ concentrations in the cluster rhizosphere solution of both soils compared with the bulk soil $(-\mathrm{P} /-\mathrm{Zn}$ ) (Table 2$)$. However, except for the $\mathrm{Zn}$ concentrations in the Anatolia cluster rhizosphere soil solution, the $\mathrm{Zn}$ and $\mathrm{Fe}$ concentrations in
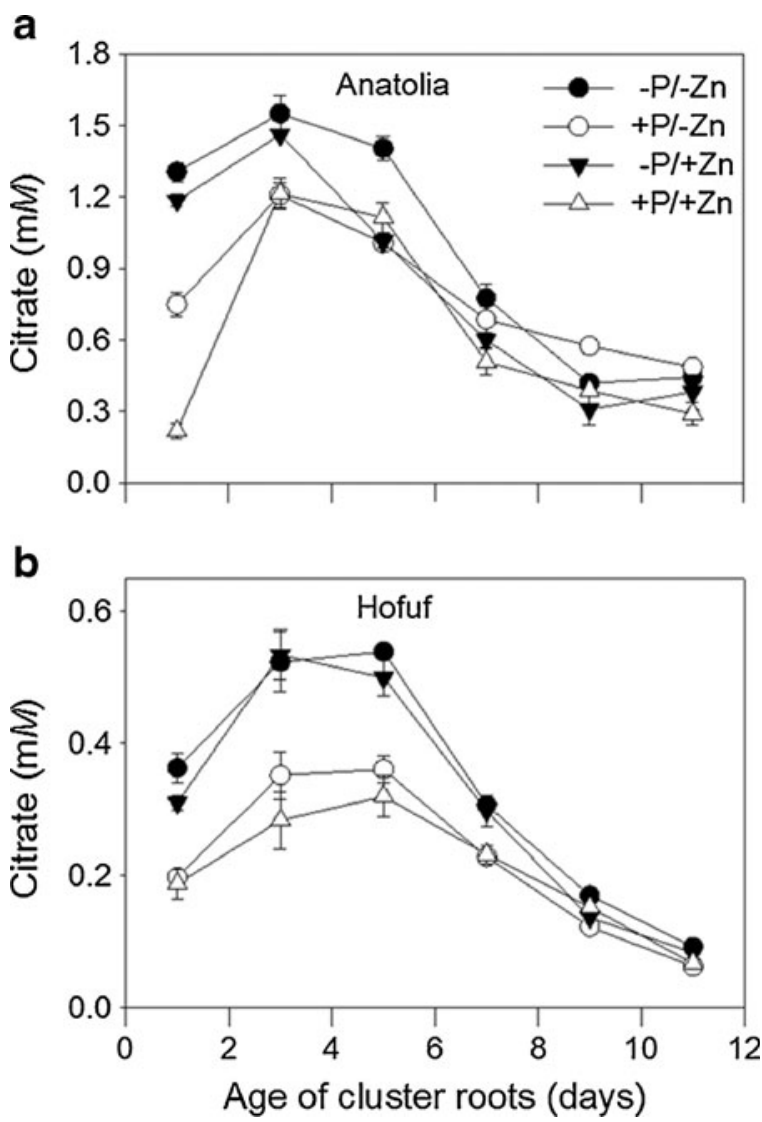

Fig. 3 Citrate concentrations in the cluster rhizosphere soil solution of the Anatolia (a) and Hofuf (b) soil depending on the age of the cluster roots. Error bars represent standard errors $(n=2)$

the cluster rhizosphere of the $-\mathrm{P}$ treatments $(-\mathrm{P} /-$ $\mathrm{Zn} ;-\mathrm{P} /+\mathrm{Zn})$ were significantly higher than in the $+\mathrm{P}$ $(+\mathrm{P} /-\mathrm{Zn} ;+\mathrm{P} /+\mathrm{Zn})$ treatments and the bulk soil $(-\mathrm{P} /-\mathrm{Zn})$, respectively (Table 2$)$. The $\mathrm{P}$ concentrations in the cluster rhizosphere of the $-\mathrm{P}$ treatments $(-\mathrm{P} /-$ $\mathrm{Zn} ;-\mathrm{P} /+\mathrm{Zn})$ were also significantly higher than in the $-\mathrm{P} /-\mathrm{Zn}$ bulk soil.

The bulk soil $\mathrm{pH}$ was almost constant over time at $\sim 7.8$ and $\sim 7.6$ in the Anatolia and Hofuf soil, respectively. The $\mathrm{pH}$ values in the soil solution of the cluster rhizosphere were increasing $\sim 3$ days after the emergence of the cluster roots (Fig. 4). Nitrate concentrations in the soil solution of the cluster root rhizosphere were higher in the $-\mathrm{P}$ treatments compared to the $+\mathrm{P}$ treatments (data not shown). In all treatments, a sharp decline of the $\mathrm{NO}_{3}$ concentrations could be observed around 3 days after the emergence of the cluster roots (data not shown). 
Table 2 Metal micronutrients and phosphorus ( $\mu \mathrm{g}$ L-1) in the soil solution of the cluster rhizosphere and the bulk soil 3 days after cluster root emergence (19 days after germination ). Values in brackets are standard errors $(n=2)$

\begin{tabular}{|c|c|c|c|c|c|}
\hline \multirow[t]{2}{*}{ Element } & \multicolumn{4}{|l|}{ Rhizosphere } & \multirow{2}{*}{$\begin{array}{l}\text { Bulk } \\
-\mathrm{P} /-\mathrm{Zn}\end{array}$} \\
\hline & $-\mathrm{P} /-\mathrm{Zn}$ & $+\mathrm{P} /-\mathrm{Zn}$ & $-\mathrm{P} /+\mathrm{Zn}$ & $+\mathrm{P} /+\mathrm{Zn}$ & \\
\hline & & & Anatolia soil & & \\
\hline $\mathrm{Zn}$ & $3.7(0.1)$ & $3.7(0.4)$ & $7.6(0.3)$ & $7.1(0.2)$ & $4.4(0.2)$ \\
\hline $\mathrm{Fe}$ & $124.0(9.0)$ & $71.2(7.0)$ & $121.5(13.5)$ & $108.5(12.5)$ & $101.7(12.0)$ \\
\hline \multirow[t]{2}{*}{$\mathrm{P}$} & $29.6(5.3)$ & $423.5(34.5)$ & $36.9(3.4)$ & $438.5(17.5)$ & $17.8(3.5)$ \\
\hline & & & Hofuf soil & & \\
\hline $\mathrm{Zn}$ & $19.9(0.6)$ & $9.9(0.3)$ & $21.8(0.6)$ & $13.4(0.5)$ & $7.8(0.8)$ \\
\hline $\mathrm{Fe}$ & $131.0(5.2)$ & $98.9(4.7)$ & $136.9(11.3)$ & $107.6(16.5)$ & $119.0(5.6)$ \\
\hline $\mathrm{P}$ & $143.2(27.4)$ & $563.3(9.6)$ & $192.5(9.1)$ & $582.2(20.3)$ & $68.9(3.6)$ \\
\hline
\end{tabular}

\section{Extraction experiment}

After shaking soil samples in a citrate solution, adsorbed citrate (difference between the added amount of citrate and the remaining citrate in solution) appeared to be linearly related to citrate concentration in the extract. The highest added concentration of citric acid $(7 \mathrm{mM})$ resulted in 1.3-1.7 $\mathrm{m} M$ citrate in solution after reaching equilibrium (24 h) (Fig. 5a). The $\mathrm{pH}$ values in the

a

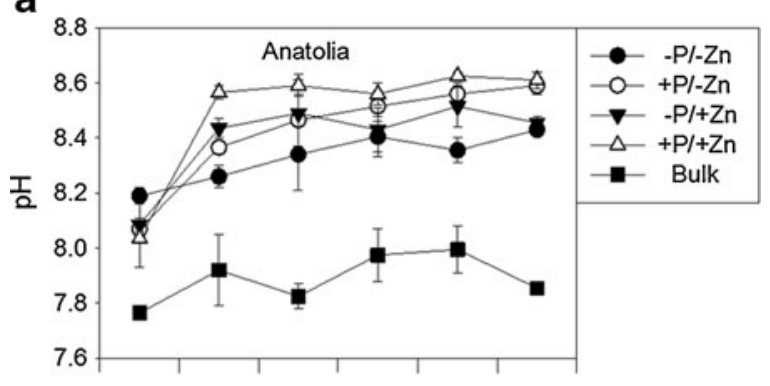

b

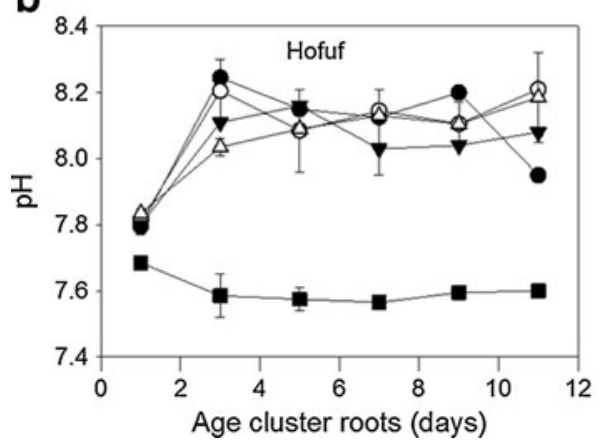

Fig. $4 \mathrm{pH}$ in the soil solution of cluster rhizosphere or bulk soil of the Anatolia (a) and Hofuf (b) soil depending on the age of the cluster roots. Error bars represent standard errors $(n=2)$ extractants of the two soils were decreasing with an increasing citrate concentration in solution. In the

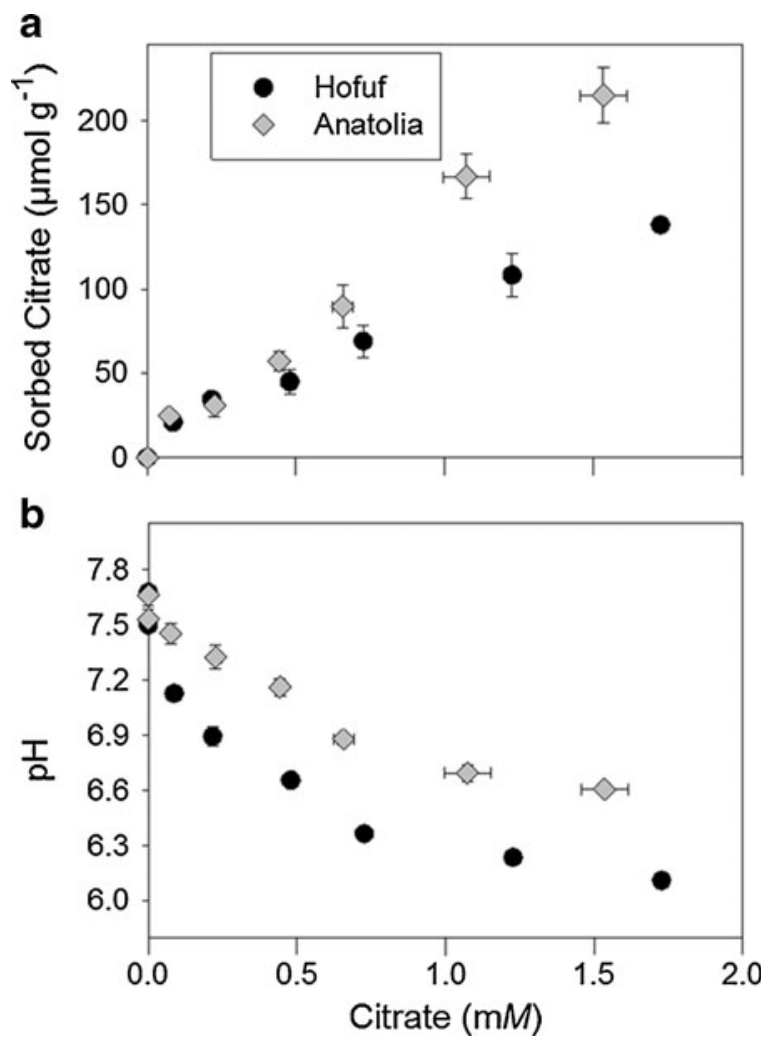

Fig. 5 Adsorption isotherms of citrate (a) on the Anatolia and Hofuf soil and the $\mathrm{pH}(\mathbf{b})$ after $24 \mathrm{~h}$ shaking $\left(20^{\circ} \mathrm{C}\right)$. $\mathrm{pH}$ changes following shaking the soils in solutions of citric acid in $10 \mathrm{mM}$ $\mathrm{CaCl} 2$ for $24 \mathrm{~h}$ at $1: 10$ soil:solution ratio. Citrate concentrations in solution ( $\mathrm{x}$ axis) were measured after centrifuging the resulting suspensions, and the amounts of citrate sorbed were inferred from the changes in solution concentrations. Error bars represent standard errors $(n=2)$ 
Anatolia soil, the $\mathrm{pH}$ decreased approximately 1 unit at the highest citrate concentrations in solution, whereas in Hofuf soil, the $\mathrm{pH}$ decreased approximately 1.3 units (Fig. 5b). Extractable P increased linearly with the citrate concentration added. Extracted $\mathrm{P}$ from the Hofuf soil was about 40 times higher compared to the Anatolia soil (Fig. 6a). Extractable Zn increased with the citrate concentration added in the Hofuf soil. No $\mathrm{Zn}$ was extracted at all from the Anatolia soil regardless of the original citrate concentration in the extractant (Fig. 6b).

\section{Discussion}

We showed that white lupin did not respond to $\mathrm{Zn}$ deficiency with cluster root formation and citrate
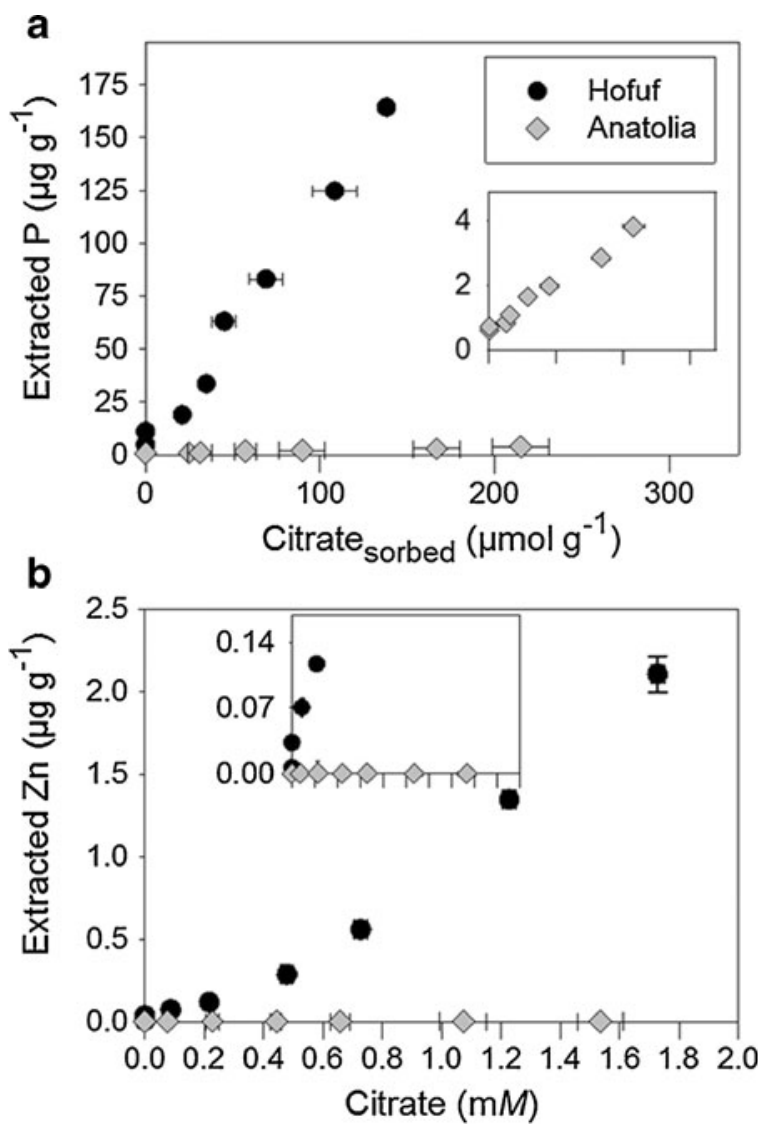

Fig. 6 Relationships between the extractable P in the extractant and sorbed citrate (a) and between the extractable $\mathrm{Zn}$ in solution and the citrate concentration in the extractant (b) after $24 \mathrm{~h}$ shaking at $20{ }^{\circ} \mathrm{C}$ of the Anatolia and Hofuf soil. The $\mathrm{x}$-axis ticks and values of the inserted small graphs are the same as of the main graphs, respectively. Error bars represent standard errors $(n=2)$ exudation. Even plants grown in nutrient solution in the absence of any $\mathrm{Zn}$ neither formed cluster roots (Fig. 1) nor exuded any detectable citrate. Zn deficiency caused no increase in citrate concentration in the soil solution around cluster roots, even though $\mathrm{Zn}$ shoot tissue content was at a critical level (Reuter et al. 1997). Neumann et al. (2000) studied the physiological aspects of cluster root function and development of white lupine and suggested that cluster root induction may be stimulated by low Zn-supply. Our experiments did not confirm this suggestion. Cluster root formation and citrate exudation were increased as a response to low $\mathrm{P}$ shoot tissue concentrations (Fig. 3) as shown before (Dinkelaker et al. 1995; Neumann et al. 2000). The citrate concentration in the soil solution peaked 3 days after the cluster root emergence, followed by a rapid decline which was also observed by Peñaloza et al. (2002) and DessureaultRompré et al. (2006).

To our knowledge we for the first time determined citrate, metal and $\mathrm{P}$ concentrations in the rhizosphere of calcareous soils. The maximum citrate concentrations we detected can be considered as high compared with other studies in a non-calcareous soil (DessureaultRompré et al. 2007). The highest citrate concentration $(\sim 1.5 \mathrm{mM})$, which was detected in the cluster rhizosphere soil solution of the Anatolia soil (-P treatments) (Fig. 6), did mobilize P, but not $\mathrm{Zn}$ (Table 2). In the Hofuf soil the highest citrate concentration $(\sim 0.5 \mathrm{~m} M)$ (-P treatment) (Fig. 6) mobilized both $\mathrm{P}$ and $\mathrm{Zn}$ (Table 2). The conclusion that $\mathrm{P}$ (and $\mathrm{Zn}$ ) were mobilized is based on a comparison of $\mathrm{P}$ and $\mathrm{Zn}$ concentrations in the soil solution of the cluster rhizosphere of the $-\mathrm{P}$ treatments with the $+\mathrm{P}$ treatments and with the $-\mathrm{P} /-\mathrm{Zn}$ bulk soil (Table 2 ). The $\mathrm{P}$ concentrations in the cluster rhizosphere solution in the $-\mathrm{P}$ treatments were, due to mobilization, 5-7 times higher in the Hofuf soil than in the Anatolia soil (Table 2) and resulted in adequate shoot $\mathrm{P}$ tissue contents in all treatments (Reuter et al. 1997). Zinc mobilization by citrate in the $-\mathrm{P}$ treatments of the Hofuf soil (Table 2) was the reason that the $\mathrm{Zn}$ fertilization had no significant main effect due to the adequate $\mathrm{Zn}$ shoot tissue contents in the $-\mathrm{P} /-\mathrm{Zn}$ treatment. This shows that the exuded citrate in the Hofuf soil was able to increase $\mathrm{Zn}$ mobilization and $\mathrm{Zn}$ plant uptake.

Zinc was not mobilized by citrate in the Anatolia soil neither in the rhizobox (Table 2) nor in the extraction experiment (Fig. 6b), even though the citrate 
concentrations in the cluster rhizosphere solution were $\sim 3$ times higher than in the Hofuf soil. This difference in $\mathrm{Zn}$ mobilization can be explained by $\mathrm{Fe}-\mathrm{Zn}$ competition. Both soils had similar aqua regia extractable $\mathrm{Zn}$ concentrations. The DTPA-extractable $\mathrm{Zn}$ was about a fifth of that in the Anatolia soil, whereas the DTPA-extractable Fe was twice that high as in the Hofuf soil (Table 1$)$. Considering the stability constants ( $\log \mathrm{K}$, based on MINTEQA2 (Allison et al. 1991)) of citrate with $\mathrm{Fe}(\mathrm{III})$ (13.1) and $\mathrm{Zn}$ (6.21), citrate probably mainly formed complexes with Fe. This is in line with the changes in Fe and $\mathrm{Zn}$ concentrations in the soil solution of the cluster root rhizosphere when the citrate concentrations reached their maximum (Table 2). Hence, in the Anatolia soil, less $\mathrm{Zn}$ was complexed with citrate in solution and, by inference, less $\mathrm{Zn}$ was desorbed or dissolved from the soil solid to replenish $\mathrm{Zn}$ taken up by the roots. The $\mathrm{Zn}$ extraction efficiencies of citrate (\% release as mol $\mathrm{Zn}$ per mol citrate in solution) in Hofuf and Anatolia soils were $0.19 \%$ and $<0.00 \%$, respectively. Therefore, metal competition in the soil solution should be considered when evaluating the mobilization capacity of citrate (or another ligand) for $\mathrm{Zn}$ (Kinniburgh et al. 1999).

Phosphorus, in contrast, was most probably mobilized due to competitive adsorption of phosphate and citrate on metal (hydr)oxides (Geelhoed et al. 1998). In the extraction experiment, 40 times more $\mathrm{P}$ was extracted from the Hofuf soil (Fig. 6a), which had about 8.5 times less Citrate Bicarbonate Dithionite (CBD) extractable Fe (Table 1) than the Anatolia soil. Since the CBD-extractable $\mathrm{Fe}$ is considered to represent the total iron (hydr)oxide content (Hiemstra et al. 2010), there was a stronger competition between $\mathrm{P}$ and citrate in the Hofuf soil. In the Anatolia soil, more citrate was bound in total (Fig. 5a), but the competition was less strong.

Other authors reported that, due to P deficiency, an increased exudation of citrate leads to a decrease of the soil pH (Neumann and Römheld 1999; Sas et al. 2001) and a correspondingly higher mobility of $\mathrm{P}$ and $\mathrm{Zn}$. However, in our rhizobox experiment, citrate exudation caused no $\mathrm{pH}$ decrease since the high $\mathrm{NO}_{3}{ }^{-}$uptake of the plant and the corresponding excess of negative charges was counterbalanced by releasing equivalent amounts of $\mathrm{OH}$ or $\mathrm{HCO}_{3}{ }^{-}$ into the rhizosphere (Imas et al. 1997). This implies that the citrate release from the root was small compared with the intake of nutrient ions and that organic anion release not necessarily acidifies the rhizosphere. Therefore, a $\mathrm{pH}$ decrease was excluded to explain the mobilization of $\mathrm{P}$ and $\mathrm{Zn}$. In the extraction experiment without plant-soil interactions, the $\mathrm{pH}$ value decreased (Fig. 5). This explains why the relative amount of mobilized $\mathrm{P}$ and $\mathrm{Zn}$ in the extraction experiment was higher than in the rhizobox experiment. The stronger $\mathrm{pH}$ decrease in the Hofuf soil was explained with the lower $\mathrm{CaCO}_{3}$ content compared with the Anatolia soil.

We conclude that white lupin does not respond to low $\mathrm{Zn}$ supply with increased citrate exudation by cluster root formation, as was shown at low P supply, which is not supportive of a multiple stress response. However, citrate exudation can, dependent on the type of soil, mobilize both $\mathrm{Zn}$ and P. To improve the understanding of the mechanisms which control $\mathrm{Zn}$ mobilization by root exudates in (calcareous) low $\mathrm{Zn}$ soils requires metal speciation techniques and mechanistic multicomponent modeling such as those used in studies with polluted soils (Koopmans et al. 2008).

Acknowledgments The authors wish to thank Eef Velthorst for providing the Capillary Electrophoresis equipment and expertise, Peter Nobels for the ICP-MS analyses, Ismail Cakmak (Sabanc1 University) and Pascal Weijters (AkzoNobel Micronutrients) for providing the soil samples from Anatolia and Hofuf, respectively. We greatly acknowledge Sjoerd van der Zee for critical reading of this manuscript, and Angela Straathof for language editing. This work was funded by the NWO (Netherlands Organization for Scientific Research).

Open Access This article is distributed under the terms of the Creative Commons Attribution License which permits any use, distribution, and reproduction in any medium, provided the original author(s) and the source are credited.

\section{References}

Allison JD, Brown DS, Novo-Gradac KJ (1991) MINTEQA2/ PRODEFA2, a geochemical assessment model for environmental systems: version 3.0 user's manual. Environmental Research Laboratory, Office of Research and Development, U.S. Environmental Protection Agency

Alloway BJ (2009) Soil factors associated with zinc deficiency in crops and humans. Environ Geochem Health 31:537-548

Cakmak I, Yilmaz A, Kalayci M, Ekiz H, Torun B, Erenoğlu B, Braun HJ (1996) Zinc deficiency as a critical problem in wheat production in Central Anatolia. Plant Soil 180:165172

Catlett KM, Heilb DM, Lindsayc WL, Ebingerd MH (2002) Soil chemical properties controlling zinc ${ }^{2+}$ activity in 18 Colorado soils. Soil Sci Soc Am J 66:1182-1189

Chaney RL (1988) Plants can utilize iron form Fe-N, N'-di-(2hydroxybenzoyl)-ethylenediamine- $\mathrm{N}, \mathrm{N}^{\prime}$-diacetic acid, a ferric chelate with 106 greater formation constant than Fe-EDDHA. J Plant Nutr 11:1033-1050 
Degryse F, Verma VK, Smolders E (2008) Mobilization of $\mathrm{Cu}$ and $\mathrm{Zn}$ by root exudates of dicotyledonous plants in resinbuffered solutions and in soil. Plant Soil 306:69-84

Dessureault-Rompré J, Nowack B, Schulin R, Luster J (2006) Modified micro suction cup/rhizobox approach for the insitu detection of organic acids in rhizosphere soil solution. Plant Soil 286:99-107

Dessureault-Rompré J, Nowack B, Schulin R, Luster J (2007) Spatial and temporal variation in organic acid anion exudation and nutrient anion uptake in the rhizosphere of Lupinus albus L. Plant Soil 301:123-134

Dessureault-Rompré J, Nowack B, Schulin R, Tercier-Waeber ML, Luster J (2008) Metal solubility and speciation in the rhizosphere of Lupinus albus cluster roots. Environ Sci Technol 42:7146-7151

Dinkelaker B, Hengeler C, Marschner H (1995) Distribution and function of proteoid roots and other root clusters. Bot Acta 108:183-200

Gao X, Zhang F, Hoffland E (2009) Malate exudation by six aerobic rice genotypes varying in zinc uptake efficiency. $\mathrm{J}$ Environ Qual 38:2315-2321

Gardner WK, Parbery DG, Barber DA (1982) The acquisition of phosphorus by Lupinus albus L. - I. Some characteristics of the soil/root interface. Plant Soil 68:19-32

Geelhoed JS, Hiemstra T, Van Riemsdijk WH (1998) Competitive interaction between phosphate and citrate on goethite. Environ Sci Technol 32:2119-2123

Geelhoed JS, Van Riemsdijk WH, Findenegg GR (1999) Simulation of the effect of citrate exudation from roots on the plant availability of phosphate adsorbed on goethite. Eur J Soil Sci 50:379-390

Göttlein A, Hell U, Blasek R (1996) A system for microscale tensiometry and lysimetry. Geoderma 69:147-156

Hiemstra T, Antelo J, Rahnemaie R, Van Riemsdijk WH (2010) Nanoparticles in natural systems I: the effective reactive surface area of the natural oxide fraction in field samples. Geochim Cosmochim Acta 74:41-58

Hinsinger P (2001) Bioavailability of soil inorganic P in the rhizosphere as affected by root-induced chemical changes: a review. Plant Soil 237:173-195

Hinsinger P, Plassard C, Tang C, Jaillard B (2003) Origins of root-mediated $\mathrm{pH}$ changes in the rhizosphere and their responses to environmental constraints: a review. Plant Soil 248:43-59

Hoffland E (1992) Quantitative evaluation of the role of organic acid exudation in the mobilization of rock phosphate by rape. Plant Soil 140:279-289

Hoffland E, Wei C, Wissuwa M (2006) Organic anion exudation by lowland rice (Oryza sativa L.) at zinc and phosphorus deficiency. Plant Soil 283:155-162

Holmgren GG (1967) A rapid citrate-dithionite extractable iron procedure. Soil Science Society of America Proceedings $31: 210-211$

Houba VJG, Temminghoff EJM, Gaikhorst GA, Van Vark W (2000) Soil analysis procedures using $0.01 \mathrm{M}$ calcium chloride as extraction reagent. Commun Soil Sci Plant Anal 31:1299-1396

Imas P, Bar-Yosef B, Kafkafi U, Ganmore-Neumann R (1997) Release of carboxylic anions and protons by tomato roots in response to ammonium nitrate ratio and $\mathrm{pH}$ in nutrient solution. Plant Soil 191:27-34
Jaitz L, Mueller B, Koellensperger G, Huber D, Oburger E, Puschenreiter M, Hann S (2011) LC-MS analysis of low molecular weight organic acids derived from root exudation. Anal Bioanal Chem 400:2587-2596

Kalis EJJ, Temminghoff EJM, Visser A, Van Riemsdijk WH (2007) Metal uptake by Lolium perenne in contaminated soils using a four-step approach. Environ Toxicol Chem 26:335-345

Kinniburgh DG, Van Riemsdijk WH, Koopal LK, Borkovec M, Benedetti MF, Avena MJ (1999) Ion binding to natural organic matter: competition, heterogeneity, stoichiometry and thermodynamic consistency. Colloids Surf, A Physicochem Eng Asp 151:147-166

Kirk GJD, Santos EE, Findenegg GR (1999) Phosphate solubilization by organic anion excretion from rice (Oryza sativa L.) growing in aerobic soil. Plant Soil 211:11-18

Koopmans GF, Schenkeveld WDC, Song J, Luo Y, Japenga J, Temminghoff EJM (2008) Influence of EDDS on metal speciation in soil extracts: measurement and mechanistic multicomponent modeling. Environ Sci Technol 42:11231130

Lindsay WL, Norvell WA (1978) Development of a DTPA soil test for zinc, iron, manganese, and copper. Soil Sci Soc Am J 42:421-428

Luster J, Göttlein A, Nowack B, Sarret G (2009) Sampling, defining, characterising and modeling the rhizosphere-the soil science tool box. Plant Soil 321:457-482

Neumann G, Römheld V (1999) Root excretion of carboxylic acids and protons in phosphorus-deficient plants. Plant Soil 211:121-130

Neumann G, Römheld V (2007) The release of root exudates as affected by the plant physiological status. In: Pinton R, Varanini $\mathrm{Z}$ et al (eds) The rhizosphere - biochemistry and organic substances at the soil-plant interface. CRC Press, pp 23-72

Neumann G, Massonneau A, Langlade N, Dinkelaker B, Hengeler C, Römheld V, Martinoia E (2000) Physiological aspects of cluster root function and development in phosphorus-deficient white lupin (Lupinus albus L.). Ann Bot 85:909-919

Novozamsky I, Van Eck R, Houba VJG, Van der Lee JJ (1996) Solubilization of plant tissue with nitric acid-hydrofluoric acid-hydrogen peroxide in a closed-system microwave digestor. Commun Soil Sci Plant Anal 27:867-875

Oburger E, Jones D, Wenzel W (2011) Phosphorus saturation and $\mathrm{pH}$ differentially regulate the efficiency of organic acid anion-mediated P solubilization mechanisms in soil. Plant Soil 341:363-382

Peñaloza E, Corcuera LJ, Martinez J (2002) Spatial and temporal variation in citrate and malate exudation and tissue concentration as affected by $\mathrm{P}$ stress in roots of white lupin. Plant Soil 241:209-221

Purnell H (1960) Studies of the family Proteaceae. I. Anatomy and morphology of the roots of some Victorian species. Aust J Bot 8:38-50

Quijano-Guerta C, Kirk GJD, Portugal AM, Bartolome VI, McLaren GC (2002) Tolerance of rice germplasm to zinc deficiency. Field Crop Res 76:123-130

Reuter DJ, Robinson JB, Dutkiewicz C (1997) Plant analysis: an interpretation manual. CSIRO, Collingwood

Rose MT, Rose TJ, Pariasca-Tanaka J, Widodo B, Wissuwa M (2011) Revisiting the role of organic acids in the bicarbonate 
tolerance of zinc-efficient rice genotypes. Funct Plant Biol 38:493-504

Sas L, Rengel Z, Tang C (2001) Excess cation uptake, and extrusion of protons and organic acid anions by Lupinus albus under phosphorus deficiency. Plant Sci 160:1191-1198

Schenkeveld WDC, Dijcker R, Reichwein AM, Temminghoff EJM, Van Riemsdijk WH (2008) The effectiveness of soilapplied FeEDDHA treatments in preventing iron chlorosis in soybean as a function of the o, o-FeEDDHA content. Plant Soil 303:161-176

Shen J, Hoffland E (2007) In situ sampling of small volumes of soil solution using modified micro-suction cups. Plant Soil 292:161-169

Sillanpää M, Vlek PLG (1985) Micronutrients and the agroecology of tropical and Mediterranean regions. Fert Res 7:151-167

Walinga I, Kithome M, Novozamsky I, Houba VJG, Van der Lee JJ (1992) Spectrophotometric determination of organic carbon in soil. Commun Soil Sci Plant Anal 23:1935-1944

Weisskopf L, Abou-Mansour E, Fromin N, Tomasi N, Santelia D, Edelkott I, Neumann G, Aragno M, Tabacchi R, Martinoia E (2006) White lupin has developed a complex strategy to limit microbial degradation of secreted citrate required for phosphate acquisition. Plant Cell Environ 29:919927

Weng L, Vega FA, Van Riemsdijk WH (2011) Competitive and synergistic effects in $\mathrm{pH}$ dependent phosphate adsorption in soils: LCD modeling. Environ Sci Technol 45:84208428

Wenzel WW, Wieshammer G, Fitz WJ, Puschenreiter M (2001) Novel rhizobox design to assess rhizosphere characteristics at high spatial resolution. Plant Soil 237:37-45

Westergaard B, Hansen HCB, Borggaard OK (1998) Determination of anions in soil solutions by capillary zone electrophoresis. Analyst 123:721-724

Widodo B, Broadley MR, Rose T, Frei M, Pariasca-Tanaka J, Yoshihashi T, Thomson M, Hammond JP, Aprile A, Close TJ, Ismail AM, Wissuwa M (2010) Response to zinc deficiency of two rice lines with contrasting tolerance is determined by root growth maintenance and organic acid exudation rates, and not by zinc-transporter activity. New Phytol 186:400-414

Zhu Y-G, Smith SE, Smith FA (2001) Zinc (Zn)-phosphorus (P) Interactions in Two Cultivars of Spring Wheat (Triticum aestivum L.) Differing in P Uptake Efficiency. Ann Bot 88:941-945 